\title{
ANNOTATIONS
}

\section{Fluorescent Textiles}

A correspondent has sent us a cutting from The Scotsman of December 21, 1945, headed "Fluorescent Textile" which concerns a spectacular discovery in the chemistry of textiles. Military secrecy being now lifted gives an "explanation, particularly in the United States of America, for the consumption of what had seemed to be fantastic quantities of a 'luxury' fabric-cellulose actetate satin." An incredible number of yards of this fabric were turned into photo-luminescent signal devices for ground troops and carrier crews to communicate with aircraft. This fabric apparently has the power of converting ultra-violet and other high-frequency radiations from the sun into lower-frequency energy, emitted as coloured light with high visibility.

Early in the African campaign an orange bunting was widely used; it reflected only the orange of the sun's rays and all the rest of the spectrum was wasted. The new textile reflects in like manner but is also able to convert much of the ultra-violet, blue and green into orange. Battle tests proved that the new fabric had, even under adverse conditions, a visibility four times that of the corresponding hue in the signal fabrics hitherto used.

This is only a single instance of the thousands where scientific facts have been turned to war uses. When the full story of all the discoveries and adaptations to war purposes is told it will make a wonderful record of achievement and be of the greatest interest to scientists and laity alike. Colour in camouflage is well known. One has only to look at certain kinds of moths resting on tree trunks to appreciate how well they tone in with their surroundings. Khaki, and we suppose the field grey of the German uniform, and even in some instances the tartan of certain Scottish clans, all make for hiding as far as possible the man from his enemies.

In this new discovery we have the other side of the picture, where colour is of the greatest assistance.

\section{A Problem for the Ophthalmic Surgeon}

A good many years ago a retired merchant skipper consulted the writer about a cataract in the right eye. There was no doubt at all about this eye and perception and projection were perfect. The lens of the other eye showed some peripheral changes but the central part was clear and allowed us to get a good view of the fundus. There was much sclerosis of the retinal vessels and a good many retinal haemorrhages, some of them in the macular area. This eye had not much central vision and it debarred him from doing his 
work. So far as memory serves us he was an assessor in the Admiralty Court, and had to read documents and interpret maps and plans. His age was 68 years and he was due to retire in eighteen months' time. If he could continue at his work till he was 70 years of age he would retire on a small pension; but if he retired before 70 then he got no pension. Here was a pretty problem. We pointed out to him that, in view of the changes in the fundus of the eye we could examine, an operation for cataract was a more risky procedure than usual and that even if the operation were successful we could not promise that the fundus of the right eye would not show signs of disease as in the left. $\mathrm{He}$ said he quite understood this; in fact the uncertainty and possible failure had been insisted on by another ophthalmic surgeon whom he had consulted. But the latter had professed his willingness to undertake the risk and he hoped that we would be able to help him. Naturally we asked why he had not kept with his previous consultant, and then it came out that the question of fees was the stumbling block. Machaon's lowest fee was beyond the means of him whom we will call Binnacle, though it wasn't his name.

The operation was performed at Binnacle's own home and no untoward event occurred. During the post-operative week he got a sharp attack of gout in his big toe, from which we augured that the eye would do well. It did, and he got $6 / 9$ vision with his glass and was able to complete his service and take lis pension. A few years afterwards ne had a slight stroke and asked us to go and see him as his sight had failed. He thought that perhaps a needling operation would restore it, but on examination the fundus was affected as that of the other eye and we had to tell him that no further operation would be of any use. We heard that he died not long after this. In this instance the result justified the risk, but we should not have cared to undertake many such cases.

\section{ABSTRACTS}

\section{CONJUNCTIVA}

(1) Rodin, F. H. (San Francisco).-Bacteriologic study of human conjunctival flora. Amer. Jl. Ophthal., Vol. XXVIII, p. 306, 1945.

(1) Rodin gives an analysis of 152 patients in whom bacteriological investigation of conjunctival scrapings was made. The scrapings were taken from the palpebral and bulbar conjunctiva by a platinum spatula. These were stained with Giemsa and by 